\title{
Improving Student Arithmetic Ability Through Interactive Multimedia Development on Mathematics Competencies of Third Grade Elementary School Students
}

\author{
Adrianus I Wayan Ilia Yuda Sukmana ${ }^{1 *}$, Ketut Pudjawan ${ }^{1}$, Desak Putu Parmiti ${ }^{1}$ \\ ${ }^{1}$ Universitas Pendidikan Ganesha, Indonesia \\ *Corresponding author. Email: aiwiy-sukmana@undiksha.ac.id
}

\begin{abstract}
Until now, Mathematics has become a subject that needs special attention because it is always seen as difficult. This stigma often causes the enthusiasm of students to take part in mathematics lessons to be lower so that it has implications for students' arithmetic abilities to become weak which is evident in learning outcomes. Referring to this problem, development research to produce interactive multimedia to improve the arithmetic operation skills of elementary school students was carried out. The objectives of this development research are 1) to describe the interactive multimedia design of arithmetic operations; 2) Describe the validity of interactive multimedia product development products on arithmetic operations through expert assessments and student group tests; and 3) To determine the effectiveness of interactive multimedia on arithmetic operations in improving students' arithmetic abilities based on learning outcomes. The development process carried out refers to the ADDIE development model stages. This study involved learning content expert, media expert and learning design expert as product validators and third grade elementary school students as research subjects.
\end{abstract}

Keywords: Interactive Multimedia, Arithmetic, Elementary School Students

\section{BACKGROUND}

Learning media is one of most important factors for optimizing student mathematics learning outcomes. Considering that mathematics has abstract characteristics then in the learning process it should be utilizing learning media which is capable of transforming abstract material becomes easy to understand. Thus, students will be interested and motivated in learning mathematics.

The findings in the field were not what was expected. Mathematics learning outcomes are still not optimal. Based on the results of interviews with mathematics teachers in one of the elementary schools in Singaraja, namely SDK Karya Singaraja, it was found that: (1) mathematics is seen as scary by students, (2) until now, a very crucial problem in mathematics is the student's ability to conceptualize arithmetic operations, (3) The problems have implications for students' enthusiasm in participating in math becomes lower, (4) lack of learning media that attracts students' interest, especially in mathematics, (5) Teachers tend to use conventional learning models. The results of this interview are in line with what has been described by Asyhar related to the factors causing mathematics learning less than optimal, namely 1) the learning method used, 2) the availability of learning resources and media that support the learning process, and 3) an environment that is interconnected with one another in supporting the learning process [1].

These issues need to handled immediately. Solution of this issues is to develop innovative media designed according to student learning needs. The use of media basically plays an important role in motivating students to learn (Bates; Heinich et al; Koumi dalam Odera, 2011). Ellingtone and Ras emphasized that students will be stimulated to learn when they are actively and emotionally involved in their learning [2].

The use of multimedia as one of the applications of computer technology makes it possible to create more interesting and interactive learning because it can combine supporting elements such as text, audio, graphics, sound, animation, and video as well as 
interactivity components into one medium. Learning materials presented with information technology media through animation, audio-visual effects are able to stimulate and motivate students to explore learning experiences and understand their learning ( $\mathrm{Li}$ in [3]). The existence of this media is certainly expected to make mathematics, especially in arithmetic operations, more interesting, fun and easy to visualize so that this can increase student interest and motivation which has implications for increasing student learning outcomes in this school. Besides referring to the above reality, the considerations underlying the selection of interactive multimedia as an innovation in mathematics learning are as follows: 1) Teachers have good abilities in using computers in learning; 2) students at SDK Karya Singaraja are very interested in learning using interactive multimedia; 3) SDK Karya Singaraja has very adequate facilities to take advantage of this learning multimedia. Based on these, this study aims to examine the effectiveness of interactive multimedia development in improving the mathematics competence of 3rd grade elementary school students.

\section{RESEARCH METHODS}

This research is a development research using the ADDIE model (Analysis, Design, Development, Implementation, Evaluation).

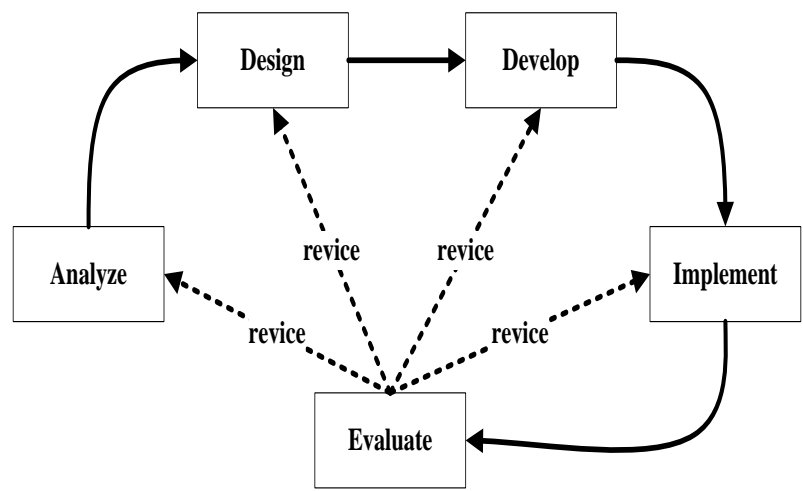

Figure 1. Phase of ADDIE Model [4]

The development procedure in this research is, 1) Analysis, which focuses on competency analysis, namely curriculum analysis to understand and measuring the level of depth demanded by the curriculum, analyzing the characteristics of learners, namely the level of initial ability of learners, learning ability, and other important aspects, and instructional analysis. Purwanto \& Sadjati explained that instructional analysis consists of a process of translating general competencies in the curriculum into specific competencies and then sort them in order to obtain a competency map contained in a chart which is then used to determine the topic [5]. 2) Design, focused on 3 activities, namely the selection of materials according to the characteristics of students and competency demands, learning strategies, assessment and evaluation methods [6]. 3) Development, focuses on content preparation and media creation activities based on the designs that have been made. 4) Implementation, carried out in 2 stages. In the first stage, a validity test was carried out by subject content experts, instructional media experts, and learning design experts. The next stage is the usability test of from mathematics multimedia learning which involves a number of students as an individual group, small group students, and large groups to find out the effectiveness of the multimedia developed. The subjects in this study were 43 grade III elementary school students. The object of this research is the learning outcomes derived from the pretest and posttest scores. Data were analyzed by nonparametric statistics with the Wilcoxon signed-rank test method. The research hypotheses tested are as follows:

$\mathrm{H}_{0}$ : There are no differences in student learning outcomes before using interactive multimedia learning and after using interactive multimedia learning.

$\mathrm{H}_{1}$ : There are differences in student learning outcomes before using interactive multimedia learning and after using interactive multimedia learning.

\section{RESULTS AND DISCUSSION RESULTS}

Based on the development stage by referring to the ADDIE development model, a learning product is produced, namely mathematics intractive multimedia learning. The following is an example of the presentation of mathematics intractive multimedia learning that has been developed.

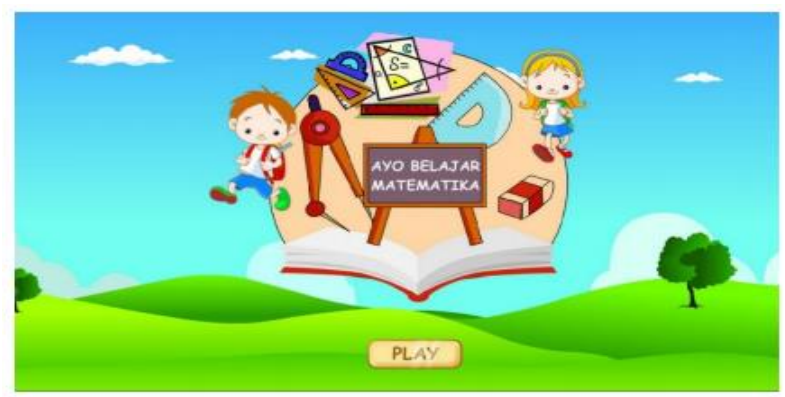

Figure 2. Introduction Page Views

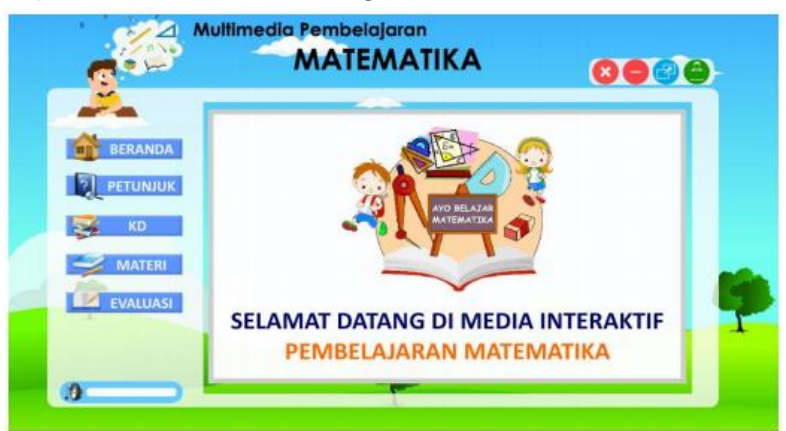

Figure 3. Home Page Views

In the implementation, before the multimedia learning examined its effectiveness in improving student learning outcomes in mathematics, this media must be tested for validation. The validation test is viewed from 3 aspects, 
namely aspects of content, learning design and willingness. The results of the content validation test obtained a score of $95.38 \%$ (in the Very Good category) while from the aspect of learning design it was obtained a score of $95.29 \%$ (Very Good category) and the last one was the validation of the media. The score obtained is 93.85\% (Very good category). The next stage before the product effectiveness test can be carried out, namely individual trials and small group trials. The individual test results obtained a score of $94 \%$ (very good category) and from the small group test results obtained a score of $93.67 \%$ which is in the very good category.

After these steps have passed, the final stage is to test the effectiveness of the product. This test is used to determine how effectively the interactive multimedia learning can improve student learning outcomes. However, before implementing this interactive multimedia learning, at the first, pretest was carried out on 43 grade III students at SDK Karya Singaraja. The pretest and posttest mean scores were 46,2 and 59,07. Based on the pretest and posttest scores of the 43 students, a non-parametric statistic test was carried out using the Wilcoxon testing method. The results of this test can be seen as below.

Table 1. Test Statistics Wilcoxon Signed Ranks Test

\begin{tabular}{|l|r|}
\hline & \multicolumn{1}{|c|}{ Posttest - Pretest } \\
\hline$Z$ & $-3.453^{\mathrm{a}}$ \\
\hline Asymp. Sig. (2-tailed) & .001 \\
\hline
\end{tabular}

Basis for a decision in the Wilcoxon test

1. If the value of Asymp. Sig. (2-tailed) $<0.05$ then $\mathrm{H}_{1}$ is accepted.

2. Conversely, If the value of Asymp. Sig. (2-tailed)> 0.05 , then $\mathrm{H}_{1}$ is rejected.

Based on the output "test statistics" it appears that Asymp. Sig. (2- tailed) has a value of 0.001 (value 0.001 $<0.05)$ so it can be stated that "H1 is accepted". Thus, it can be interpreted that there are differences in mathematics learning outcomes before using interactive multimedia learning and after using interactive multimedia learning. From these findings, it can be concluded that "there is an effect of the use of interactive multimedia learning on mathematics learning outcomes in grade III elementary school students."

\section{DISCUSSION}

Based on the data analysis that has been done, it is found that there are differences in mathematics learning outcomes before using interactive multimedia learning and after using interactive multimedia learning. From this research, there are many things that affect the improvement of student learning outcomes who using interactive multimedia this learning. In general, the aspects of content, instructional design, and aspects of the media also play a role in the improvement of student mathematics learning outcomes, especially in arithmetic abilities.

Viewed from the aspect of learning design, one that also influences is the message delivery strategy which designed to involve students activity in the learning process. According to Riswanil and Widayati, student learning activeness is all student activities in the learning process that involve emotional abilities that emphasize student creativity, increase their minimum abilities in mastering concepts [7].

Related to this, Paul D. Dierich (in Riswanil and Widayati, 2012: 7) states that learning activeness can be classified into 8 groups, namely visual, oral, listening, writing, drawing, metric, mental, and emotional activities [7]. Dimyati, Mudjiono, Sardiman explained the classifications of student activities included in learning activities, namely [7]:

1. Visual activities, which include reading, paying attention to pictures, demonstrations, experiments.

2. Oral activities, such as: stating, formulating, asking questions, giving suggestions, expressing opinions, conducting interviews, discussions, interruptions.

3. Listening activities, for example: descriptions, conversations, discussions, music, speeches.

4. Writing activities, such as writing stories, essays, reports, questionnaires, copying.

5. Drawing activities, for example: drawing, making graphs, maps, diagrams.

6. Motor activities, which include among others: doing experiments, making construction, repairing models, playing, gardening, raising livestock.

7. Mental activities, for example: responding, remembering, solving problems, analyzing, seeing relationships, making decisions.

8. Emotional activities, such as being interested, feeling bored, excited, passionate, courageous, calm, nervous.

From the list of student activities, at least there is student learning activity in this multimedia, namely: (1) Visual activities, in this activity students actively pay attention to animation and learning instruction in multimedia, (2) Listening activities, in this activity students listen all explanations about problem solving procedures, explanations of the concepts that exist in multimedia, (3) Mental activities, in this activity students respond to what is instructed in multimedia related to the problems presented in multimedia as a basic component of student learning then students are invited to analyze and solve questions solving the problem.

Related to the active role of students in the learning process of mathematics by using interactive multimedia, Smaldino et. al. explained that the advantages of using computer-based media in the student learning process, namely, [8]: 1) providing individualization of learning, 2) being able to accommodate the special needs of students, 3) able to provide monitoring of student learning outcomes, 4) enable information management, 5) provide 
multisensory learning experiences, 6) encourage and increase student participation in the learning process.

Viewed from the aspect of learning media, one of the important things is the suitability of the illustration (image / video / animation) of the material with the characteristics of the target and the message to be conveyed. Based on this, it can be seen that the format of the presentation of the material is very influential in forming students' understanding of the learning material considering that the age of 3rd grade elementary school children is in the concrete operational stage range (6-12 years).

Basically, at the concrete operational stage (6-12 years) the child is ready to use logical thinking or operations, but only for physical objects that exist today. However, without a physical object in front of them, children at the concrete operational stage still have big difficulties for completing logical tasks. (Matt Jarvis, 2011, [9]). In this regard, the illustrations (images / videos / animations) of the material poured in this multimedia have accommodated how students understand and use their logic. Here is just one example.

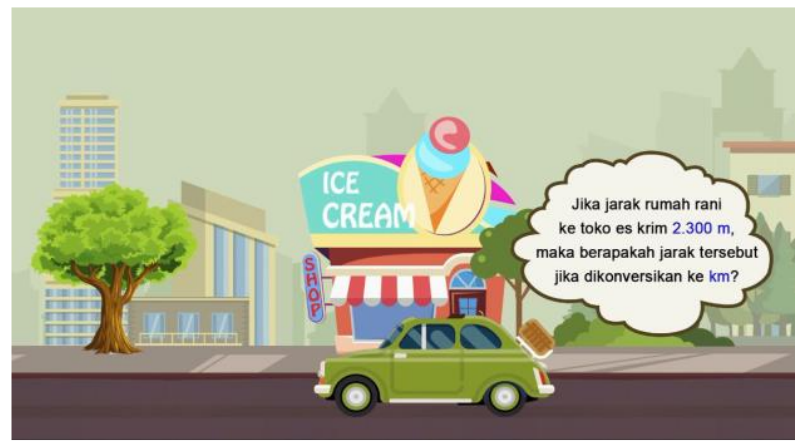

Figure 4. Example

According to the cognitive theory described by Mayer, learning based on the theory of multimedia learning (various presentations) will be effective compared to learning with sources that are only text, both on-screen and narrative [10]. Mayer further explained that the learning messages presented in the form of words and images (static images and dynamic images in the form of animation) can simultaneously help students construct their understanding more effectively through verbal and pictorial mental models and build relationships between of the two. Mayer emphasized that the process of building a relationship between verbal and pictorial mental models is an important stage in the formation of conceptual understanding. This is evidenced at the trial stage individually and in small groups. The results of individual and small group trials proved that students felt happy and interested in learning by using this interactive multimedia learning. And the results of the effectiveness test show that there are differences in learning outcomes between before and after using this multimedia learning. From this, it can be seen that the use of interactive multimedia in the mathematics learning process has a positive influence on students, especially in terms of learning motivation and the process of students knowledge construction.

With regard to motivation, it is well known that motivation is one of the most important elements in effective learning. Students who have high learning motivation tend to try to find out and understand any subject matter, including mathematics which is always a scourge for many students. As explained by Murphy \& Alexander (2000), Pintrich (2003), Schunk (2000), Stipek (2002) as a form of internal process in students, learning motivation is in charge of activating, guiding and maintaining student learning behavior from time after time [11]. In simple terms, motivation can be interpreted as a psychological force that causes a person / student to act, take steps, according to what they are interested in and like.

Motivation not only plays an important role in keeping students involved in the learning process, but more deeply, motivation also determines how much information can be received by students from the ongoing learning process. Driscoll (2005), Jetton \& Alexander (2001), Pintrich (2003) explain that students who have high motivation to learn tend to use higher cognitive processes in learning, absorbing and remembering more learning content [11]. Therefore, students motivation to learn must be increased, at least it can be maintained.

\section{CLOSING}

Until now, Mathematics remains a scourge for students. This has long implications for the lack of students understanding to the basic concepts of mathematics, namely arithmetic. This study shows that arithmetic skills can be improved by utilizing interactive multimedia learning to motivate and attract students interest in learning through interesting and interactive presentation through text and images (static and dynamic) that are presented simultaneously in order to construct student understanding through the relationship between of two.

\section{REFERENCES}

[1] R. Asyhar, Kreatif mengembangkan media pembelajaran, Jakarta: Referensi Jakarta, 2012.

[2] F. Y. Odera, Motivation: The Most Ignored Factor In Classroom Instruction In Kenyan Secondary Schools, in: International Journal of Science and Technology, Vol. 1(6), 2011, pp. 283-288. Available at: http://ejournalofsciences.org/ archive/vol1no6/vol1no6_15. Pdf.

[3] C. Y. Chen and W. L. Chung, Research on the learning effects of multimedia assisted instruction on Mandarin vocabulary for Vietnamese students: a preliminary study involving e-learning system, in: 
Educational Research Reviews, Vol. 6(17), 2011, pp. 919-927. Available http://www.academicjournals.org /err/PDF/Pdf\%202011/5Nov/Chen\%20and\%20Chu ng.pdf .

[4] R. Gagne, W. Wager, K. Golas and J. \& Keller, Principles of instructional design, 5th Ed., Belmont: CA: Wadsworth/Thomson Learning, 2005.

[5] D. Padmo, Teknologi Pembelajaran: Peningkatan kualitas belajar melalui teknologi pembelajaran, 2004.

[6] I. M. Tegeh and I. M. Kirna, Pengembangan bahan ajar metode penelitian pengembangan pendidikan dengan ADDIE model, Universitas Pendidikan Ganesha, Singaraja, 2010.

[7] Tazminar, Meningkatkan Keaktifan Belajar Dan Hasil Belajar Siswa Dengan Menggunakan Model Pembelajaran Examples Non Examples, Jupendas, Vol. 2 (1), 2015, pp. 45-57.

[8] E. S. Smaldino et. al., Teknologi Pembelajaran dan Media untuk Belajar, diterjemahkan oleh Arif Rahman dari Istrukturional Technology And Media For Learning, Jakarta: Kencana Prenada Media Grup, 2011.

[9] F. Ibda, Perkembangan Kognitif: Teori Jean Piaget, Intelektualita, Vol. 3 (1), 2015, pp. 27-38.

[10] M. R. Mayer, Multimedia learning, Diterjemahkan oleh Baroto Tavip Indrojarwo, Multimedia learning, Yogyakarta: Pustaka Pelajar, 2009.

[11] R. E. Slavin, Psikologi Pendidikan: Teori dan Praktek, Jakarta: Indeks, 2011. 